\title{
GAGASAN PEMIKIR ISLAM PROGRESIF; BERAGAMA SECARA OTENTIK DALAM KEHIDUPAN KONTEMPORER
}

\author{
Ach. Maimun \\ Institut Ilmu Keislaman Annuqayah Guluk-guluk Sumenep \\ mymoon221@gmail.com
}

\begin{abstract}
Abstrak:
Beragama secara otentik adalah idealisme penganut agama yang sungguh-sungguh. Di satu sisi beragama tidak bisa sekadar meniru dalam tradisi, tapi di sisi lain ia berhadapan dengan modernitas yang mengubah tradisi. Di satu sisi Islam terjaga dalam tradisi tapi di sisi lain kemajuan mengharuskan mengikuti modernitas. Karena itu, pertanyaan bagaimana menjadi muslim sekaligus menjadi modern adalah pertanyaan dasar dalam pencarian otentisitas beragama. Pertanyaan itu terutama dilatari oleh kesadaran atas ketertinggalan dari Barat dan upaya yang dilakukan dengan menirut Barat tidak memberikan hasil yang menggembirakan, untuk tidak menyebut gagal. Umat Islam mengalami "alienasi" dalam keagamaan dan kehidupan kontemporer. Para pemikir Islam progresif menawarkan gagasan yang beragam dalam rangka menemukan otentisitas beragama tersebut. Iqbal memberikan gagasan yang bercorak filosofis dengan mendasarkan konsepnya pada diri/jiwa yang otonom, Sayyid Quthub yang radikal mendasarkan pada konsep dasar Islam yang berseberangan dengn kejahiliahan, Ali Syari'ati yang revolusioner mendasarkan pada spirit ajaran Islam yang diterjemahkan gerakan nyata melawan berbagai bentuk tirani, dan Arkoun yang kritis dalam menggali turats dengan menggunakan perangkat-perangkat modern. Berbagai gagasan yang beragam ini dapat memberi inspirasi bagi upaya terus menerus mencari otentisitas beragama.
\end{abstract}

Kata Kunci: ashalah, turats, modernitas, alienasi.

\section{Abstract:}

Authentic religion is a religious idealism. On the one hand religion can not simply imitate in tradition, but on the other hand it deals with modernity that changes tradition. On the one hand Islam is awake in tradition but on the other hand progress requires 
following modernity. Therefore, the question of how to become Muslim and to be modern is a basic question in the quest for religious authenticity. The question is mainly due to the awareness of the backwardness of the West and the efforts made by emulating the West have not yielded encouraging results, not to mention failure. Muslims experience "alienation" in religious and contemporary life. Progressive Islamist thinkers offer diverse ideas in order to discover the religious authenticity. Iqbal gave a philosophical idea of basing his concept on autonomous self, the radical Sayyid Quthub based on the basic concept of Islam that is opposed to ignorance, the revolutionary Ali Shari'ati based on the spirit of Islamic teachings translated by real movements against various forms of tyranny, and Arkoun are critical in digging turats using modern devices. These diverse ideas can inspire the continued quest for religious authenticity.

Keywords: ashalah, turats, modernity, alienation.

\section{Pendahuluan}

Semangat keberagamaan yang terlihat dalam bentuk semaraknya simbol-simbol Islam akhir-akhirnya menyiratkan upaya pencarian otentisitas dalam keagamaan. Mereka semua memperlihatkan upaya berislam secara otentik dengan menolak atau berbeda dengan ajaran dan budaya lain. Arab menjadi rujukan karena dililai tempat lahir dan bisa memberikan Islam yang otentik. Tapi Jefrey Lang, seorang intelektual mulism Amerika, yang merasa kecewa setelah upayanya untuk mencari Islam otentik ke Arab Saudi dapat diambil sebagai salah satu contoh bahwa beragama secara otentik tidak mesti melihat ke tempat lahirnya.

Lang justru merasa cocok dengan menjadi seorang Amerika yang modern sekaligus menjadi Islam dan sebaliknya, menjadi muslim otentik tidak harus meninggalkan keamerikaannya. ${ }^{1}$ Tapi konteks otentisitas keagamaan di sini bukan dalam konteks kaitannya dengan tradisi lokal, tapi dengan konteks global, yakni kebudayaan modern. Karena kondisi ini yang membuat penganut agama (Islam) berhadapan dengan persoalan otentisitas. Modernitas sendiri, seperti dikatakan Giddens, telah menghancurkan tradisi yang menjadi tempat perlindungan apa yang selama ini dianggap sebagai otentik. Walaupun demikian,

1 Edi Susanto, "Islam Pribumi versus Islam Otentik (Dialektika Islam Universal dengan Partikularitas Budaya Lokal" Jurnal Karsa Sosial dan Budaya Keislaman STAIN Pamekasan, Vol. VIII, No 1, April 2008, 16. 
sebenarnya modernitas tetap memerlukan tradisi yang telah ada dalam menciptakan tradisi baru. ${ }^{2}$

Di dunia Arab sebagai tempat kelahiran Islam, umat Islam berhadapan dengan pertanyaan besar tentang otentisitas islam. Karena itu, dengan agak tergesa-gesa, sekelompok orang berkumpul untuk berbicara tentang masalah yang mereka anggap penting. Mereka adalah para dedengkot Arab League, Culture, and Scientific Organization (ALESCO), lalu menggagas dilaksanakannya Mu'tamar al-Ashalah wa al-Tajdid wa fi al-Tsaqafah al-'Arabiyyah al-Mu'ashirah (Konferensi tentang Otentisitas dan Perubahan dalam Kebudayaan Arab Kontemporer), tepatnya di Kairo 4-14 Oktober 1971, setahun setelah ALESCO dirikan. Menurut laporan al-Adab (edisi November 1971), memang tidak banyak cendikiawan Arab yang terlibat. Hanya ada delapan pemakalah, antara lain Zaki Najib Mahmoud, Syukri 'Ayyad dan Muhammad alMazali. ${ }^{3}$ Walaupun demikian, ia sangat penting, karena bisa membidani lahirnya konferensi intelektual Arab pada tahun 1974, yang lebih terorganisir dan lebih luas. ${ }^{4}$

Pada zamannya juga, Khaled Abou El-Fadl mengkritik lembaga fatwa seperti CRLO (Council for Scientific Research and Legal Opinion/ al-Lajnah ad-Daimah li al-Buhus al-Imiyyah wa alIfta') yang merupakan sebuah lembaga resmi di Saudi Arabi (dalam konteks keindonesiaan terdapat beberapa istilah lain, diantaranya fatwa MUI, bahsul masail, majlis terjih dll) yang mempunyai otoritas untuk mengeluarkan fatwa-fatwa keagamaan yang oleh Abou El-Fadl dianggap terjebak pada sikap otoritarianisme, seperti fatwa pelarangan wanita mengunjungi makam suami, wanita mengeraskan suara dalam berdo"a, wanita menegendarai dan mengemudikan mobil sendiri, dan wanita harus didampingi pria mahramnya. Fatwa-fatwa tersebut dianggap sebagai tindakan merendahkan untuk tidak menyebutkan menindas martabat wanita yang tidak dapat ditoleransi pada zaman sekarang. Fatwa-

2 Ahmad Sahidah, "Menemukan Islam Otentik: Menggugat Tradisi dan Modernitas" Jurnal Kontekstualita Penelitian Sosial Keagamaan IAIN Sulthan Thaha Saifuddin Jambi, Vol. 25, No. 2, 2010, 177.

3 Lihat al-Adab, November 1971, hlm. 2-27. berbagai gagasan dalam konferensi ini dikupas oleh Issa J. Boullata, Dekonstruksi Tradisi, Gelegar Pemikiran Arab Islam, terj. Imam Khoiri, LKiS, Yogyakarta, 2001, bab pertama.

4 Konferensi itu bertajuk Azmat al-Tathawwur al-Hadhari fi al-Wathan al-'Arabi, dilaksanakan di Kuwait 7-12 April 1974. Konferensi ini menampilkan 22 pemakalah dari para intelektual terkemuka Arab, yang kemudian mempengaruhi perbincangan berikutnya tentang turats, hadharah dan Ashalah. 
fatwa tersebut menurut Abou El-Fadl dikatakan berlindung dibawah teks (nash) yang mengklaim bahwa itu yang sebenarnya "dikehendaki oleh Tuhan". Menurutnya, reinterpretasi tafsir-tafsir hukum Islam penting untuk dilakukan agar umat Islam terhindar dari keotoriteran penafsir di dalam menafsirkan teks. ${ }^{5}$

Sebagai titik awal, langkah itu tentu sangat strategis dalam perbincangan tentang "otentisitas" (ashalah) dalam kaitannya dengan modenitas (mu'ashirah). Beberapa pemakalah telah cukup jelas memberikan pengertian otentisitas yang dimaksud dan menjadi kegelisahan, khususnya masyarakat. Menurut Syukri Ayyad, istilah ashalah jarang ditemukan dalam literatur Arab tahun 1920-1930. Istilah itu baru digunakan secara luas setelah tahun 1950, walaupun masih bersifat dugaan. Tapi istilah ashalah pada saat itu belum sepenuhnya mengacu pada makna otentisitas. Ia masih digunakan dalam banyak makna, misalnya individualitas, penemuan dan pembebasan dari tradisi. Dalam konteks berikutnya, ashalah diperlawankan dengan "imitasi" atas elemenelemen kebudayaan. Ia bermakna memelihara terus menerus elemen kebudayaan kuno yang original dalam kebudayaan tertentu. ${ }^{6}$

Otentisitas kemudian dikaitkan dengan "warisan" kebudayan suatu masyarakat secara umum, bahkan keseluruhan pengalaman masa lalu suatu masyarakat yang dalam wacana Arab di sebut turats (tradisi). Artinya, dalam elemen kebudayaan yang merupakan warisan bagi suatu bangsa, terdapat unsur-unsur yang harus dipertahankan untuk bekal membangun masa depan di tengah keniscayaan perubahan dalam masyarakat. Hal itu menjadi semakin prinsip ketika perubahan yang terjadi akibat masuknya unsur eksternal yang sering melahirkan imitasi kebudayaan dan meninggalkan otentisitas.

Maka ketika berbicara tentang Islam dalam kaitannya dengan pencarian otentisitas, upaya itu diarahkan untuk melihat elemen otentik Islam ditengah perjalanan sejarahnya, atau al-Jabiri menyebutnya al-islam al-haqiqi sebagai esensinya (islam dzatuh). ${ }^{7}$ Ia tidak semata tradisi. Karena tradisi tidak sepenuhnya otentik,

\footnotetext{
${ }^{5}$ Moh. Wardi, "Hermeneutika Khaled Abou El Fadl; Sebuah Kontribusi Pemikiran Dalam Studi Islam" Jurnal Al-Ulum; Jurnal Pemikiran dan Penelitian Keislaman UIM Pamekasan, Vol. 1 No. 1 Juni 2014, 1.

6 Issa J. Boullata, Mencari Islam, 19-20.

7 Mohammad Abid al-Jabiri, Nahnu wa al-Turats, (Al-Markaz al-Tsaqafi al-'Arabi, Beirut, 1993), 13. Dalam hal ini al-Jabiri mengkontraskan al-Islam al-haqiqi dengan Islam seperti dipraktekkan umat Islam saat ini (islam al-muslimin almu'ashirin).
} 
tapi tradisi dapat berbaur dengan ideologi dan tidak bisa lepas dari lokalitas locus-tempus-nya. Dalam usaha pencarian otentisitas, secara umum selalu dipertentangkan dengan modernitas. Karena kehadiran modernitas telah mengusik "ketenangan" hidup masyarakat Islam serta menciptakan perubahan-perubahan besar sehingga merancukan identitas suatu masyarakat. Dalam hal ini Robert D. Lee meletakkan upaya pencarian otentisitas di antara tradisi dan modernitas. ${ }^{8}$ Karena di satu sisi, dalam masyarakat terdapat tradisi yang cenderung tetap dan muncul modernitas yang menampilkan perubahan. Maka pencarian otentitas pada dasarnya bergerak di antara tradisi yang tetap dan modernitas memberikan perubahan, antara turats dan hadtsah. ${ }^{9}$

Sementara modernitas (hadatsah atau mu'ashirah), sebagai konsep pinjaman, adalah kondisi yang berubah sejak abad lalu. Sebagai konsep, ia memiliki dua aspek utama: (1) kontinuitas dan perubahan, (2) revolusi dan aksi sosial. ${ }^{10}$ Modernitas merupakan fenomena perubahan yang merasuk dunia Islam yang berasal dari Barat dengan berbagai muatannya. Tentu saja hal itu berakibat munculnya berbagai persoalan di tengah masyarakat yang sangat menjaga tradisi.

\section{Akar Pencarian Otentisitas}

Pencarian otentisitas dalam dunia Islam, khususnya Arab, tidak lepas dari upaya pembaharuan dalam segala bidang kehidupan. Kekalahan dari Barat sejak periode akhir Turki Usmani hingga imperealisme Barat atas negara-negara Timur Tengah telah menyadarkan masyarakat Islam atas ketertinggalannya dari Barat. "Keterkejutan" itu melahirkan usaha-usaha rintisan untuk mengejar ketertinggalan. Umumnya, mereka berusaha meniru

8 Lihat Robert D. Lee, Overcoming Tradition and Modernity: The Search for Islamic Authenticity, (Westview Press, A Division of HarperCollins Publishers, inc., 1997). Edisi Indonesianya diterbitkan Mizan dengan judul Mencari Islam Autentik, Dari Nalar Puitis Iqbal sampai Nalar Puitis Arkoun.

9 Menurut istilah al-Jabiri sebagaimana judul bukunya. Adanya banyak istilah yang menunjuk pada maksud tersebut dalam wacana Arab seperti al-turats wa al-tajdid atau al-qadim wa al-jadid (Hasan Hanafi), al-ashlah wa al-hadatsah (A. H. Jidah), al-turats wa al-mu'ashirah (A. D. Umari). Tidak jarang juga kata ashalah dimaksudkan sebagai turats atau tradisi. Tapi dalam tulisan ini, turats disebut sebagai tradisi yang diwarisi dari pengalaman dan budaya, sementara ashalah adalah sikap tertentu yang unik dalam menghadapi tradisi dan modernitas tersebut.

10 Seperti dikatakan Q. Zurayq yang dikutip Luthfi Assyaukani, "Tipologi dan Wacana Pemikiran Arab Kontemporer," dalam Jurnal Paramadina, Vol. I, No. 1, Juli-Desember,1998, 63. 
Barat, khususnya dalam konsep-konsep pembangunan seperti dirumuskan Barat di bawah bendera modernitas. ${ }^{11}$

Tapi apa daya, Arab-Islam belum maju-maju, tetap tertinggal dan belum bisa membangun diri. Para elit nasional yang meraih kekuasaan pada era pascakolonial tidak berhasil menggunakan kekuatan-kekuatan modernisasi untuk mewujudkan janji-janji manisnya. Aljazair, Mesir, Suriah, Iran dan Libya kemudian mencoba sosialisme untuk mengadaptasi modernisme dengan tradisi Arab. Tapi hal itu juga gagal. Bahkan, kata Hasan Hanafi, Arab khususnya merasa lebih lengket dengan tradisi karena telah menyatu dengan kesadaran akibat pewarisan turun temurun, sedang modernitas baru datang dari luar. ${ }^{12}$

Kemudian, Arab-Islam harus menelan pil pahit berupa kekalahan dalam peran melawan Israel 1967. Kesadaran atas pencarian otentisitas mencuat dan para intelektual Arab-Islam terlibat dalam perbincangan. Mereka mulai realistis melihat kenyataan bahwa mereka belum bisa keluar dari kungkungan ketertinggalan, padahal mereka lebih awal berkenalan dengan kemajuan Barat dari pada Jepang. Turki adalah contoh negara paling awal melakukan perubahan demi kemajuan yang dimulai dari modernisasi militer. Tapi hingga saat ini masih belum bisa mensejajarkan diri dengan Barat, terutama dalam aspek ilmu pengetahuan dan teknologi, politik dan ekonomi.

Kekecewaan atas konsep pembangunan (developmentalism) yang diadopsi dari Barat adalah kata kunci pencarian serius otentisitas. Pada tahun 1960-an dan 1970-an negara-negara baru di Afrika dan Asia membutuhkan lebih banyak modal, sekolah, fasilitas komunikasi, industri dan alih teknologi. Segalanya mencerminkan pengalihan segala yang dianggap perlu dari pola pembangunan ekonomi Barat. ${ }^{13}$ Tapi hasilnya ternyata tidak positif. Karena itu mereka terdorong untuk mencari potensi sendiri. Umumnya mereka merujuk pada pengalaman kejayaan Islam masa lalu. Islam dapat maju sebelum bersentuhan dengan modernisasi Barat, apalagi dengan developmentalisme. ${ }^{14}$

11 Harun Nasution, Pembaharuan Pemikiran dalam Islam, (Bulan Bintang, Jakarta, 1980), 34.

12 Hasan Hanafi, Muqaddimah fi 'Ilm al-Istighrab, (Kairo: Maktabh Wahbah, 1991), 15.

13 Robert D. Lee, Mencari Islam, 11.

14 Kesadaran masa lalu itu kemudian melahirkan aliran romantik yang selalu berfantasi dengan kejayaan masa lalu, berpegang teguh pada warisan masa silam dan anti perubahan. Kelompok ini menjadi salah satu kelompok dari tiga kelompok dalam menyikapi pencarian otentisitas. Issa J. Boullata, Dekonstruksi Tradisi, 17. 
Kegagalan itu kemudian dicurigai karena berasal dari Barat dan tidak cocok dengan kultur Arab-Islam. Maka, pencarian otentisitas pun dimulai dengan berbagai kajian dan debat, tentang tentang unsur yang harus dipertahankan, dibuang, dimodifikasi serta perubahan yang harus dilakukan dalam kehidupan umat Islam. Pencarian otentisitas dianggap menjadi titik tumpu terpenting dalam upaya pembangunan secara umum. Karena ia adalah modal besar suatu bangsa untuk menatap hari depannya.

Revolusi Iran 1979 menjadi peristiwa penting yang semakin menguatkan resistensi konsep-konsep pembangunan yang diimpor dari Barat. Keyakinan bahwa modernitas dalam arti konsep yang dicanangkan Barat untuk dunia ketiga tidak bisa diuniversalisasi semakin kental. Ia belum tentu bisa dipraktekkan di dunia lain dan kenyataannya tidak bisa mewujudkan kemajuan yang dijanjikan. Maka pencarian otentisitas merupakan hal yang lebih penting dari kebutuhan akan konsep-konsep pembangunan .15

Walaupun demikian, penolakan terhadap modernitas atas nama pencarian otentisitas tidak berarti mempertahankan status quo dan anti perubahan. Para pemikir Islam tidak setuju dengan stigma dualistik, bahwa Barat modern dan dinamis sedang Timur tradisional dan statis. Bagi para pencari otentisitas, kehidupan harus selalu diperbaiki dan modernitas telah menjadi fenomena global dan menciptakan perubahan di seluruh dunia. Karena itu perubahan adalah keniscayaan dan modernisasi tidak bisa dibendung. Persoalannya, bagaimana menjadi modern dengan cara "saya sendiri". ${ }^{16}$ Berarti pencarian otentisitas mengandaikan inovasi dan kreativitas membangun formula yang tepat untuk hidup lebih baik.

\section{Belajar dari Para Pemikir Progresif}

Telah banyak pemikir yang turut menyumbangkan gagasannya tentang pencarian otentisitas dengan gagasangagasannya yang brilian dan orisinil. Di antaranya adalah Mohammad Iqbal, Sayyid Qutub, Ali Syari'ati dan Mohammed Arkoun. Keempat tokoh ini telah memberikan pemikiran yang banyak mempengaruhi pemikir selanjutnya. Masing-masing memang memiliki gaya dan ciri khas, kaitannya dengan usaha pencarian otentisitas.

Pertama, Muhammad Iqbal. Dengan begitu bangga Syed Abdul Vahid menyatakan bahwa tak ada orang yang seserba bisa,

\footnotetext{
15 Robert D. Lee, Mencari Islam, 11.

16 Ibid. 14.
} 
produktif dan jenius seperti Iqbal. Dia bisa disejajarkan dengan tokoh-tokoh besar seperti Michelangelo, Leonardo da Vinci dan Rabinrdranath Tagore. ${ }^{17}$ Gagasannya tentang otentisitas menjadi penting karena ia sangat berpengaruh pada pemikir modern dalam upayanya untuk membebaskan kemanusiaan dari kungkungan mistisisme Timur (serta mullahisme dan monarki) dan materialisme Barat sekaligus. Attaturk dan Reza Syah adalah dua figur tiran yang membelenggu pada dua kutub kemanusiaan. ${ }^{18}$

Menurut Iqbal, umat Islam telah mengalami "erosi identitas". Mereka tidak lagi mengenal siapa diri mereka sebenarnya. Identitas itu tentu saja tidak bisa dibangun dari semata komitmen atas tradisi atau nasionalisme. Tapi ia harus beranjak dari pemahaman eksistensial tentang diri sendiri. Maka ide utama Iqbal adalah regenerasi kemanusiaan melalui perjuangan individu tanpa henti untuk menyempurnakan realisasi diri. ${ }^{19}$

Erosi identitas itu salah satunya merupakan dampak dari imperealisme Barat yang tidak saja menciptakan ketergantungan ekonomi dan politik, tapi juga psikologis. Islam semakin tenggelam dalam diri yang tidak autentik dalam menyikapi kehidupan, mengalami kematian keberanian, imajinasi dan heroisme. Maka proyek Iqbal adalah melepas pengaruh penjajahan, merombak mistisisme Timur yang membunuh pikiran dan dan materialisme Barat yang membunuh kehendak. ${ }^{20}$

Diri autentik adalah diri yang mengangkat nilai-nilai revolusioner Nabi Muhammad, yaitu diri yang kuat, bersemangat dan otonom. ${ }^{21}$ Ia merupakan diri yang mampu menyatukan religiusitas Timur dan rasionalitas Barat. Mistisisme Timur ditolak karena cenderung membunuh rasionalitas dan menyingkir dari kehidupan. ${ }^{22}$ Padahal diri autentik hakikatnya adalah menyatu dengan Tuhan yang diwujudkan dengan penyatuan dengan kehidupan dunia. Walaupun kehidupan dunia penuh hukumhukum keniscayaan, tapi muslim sejati dapat melampauinya

17 Lihat Syed Abdul Vahid, Iqbal, His Art and Thought, (Lahore: Ashraf, 1944), 3.

18 Lihat Mohammad Iqbal, Poems from Iqbal, terj. V.G. Kiernan, Murray (London, 1955), 72.

19 Fazlur Rahman, "Iqbal and Mysticism," dalam Iqbal as a Thinker, Ashraf, (Lahore, 1944), 223. Lihat puisi Iqbal: Hatimu adalah lilinmu//Dirimu sendiri adalah seluruh cahaya yag kau dambakan//kaulah satu-satunya kebenaran dunia ini, yang lain tidak//ilusi laksana sihir. Terjemahan bebas dari petikan puisi Iqbal dalam Poems from Iqbal, 31.

20 Robert D. Lee, Mencari Islam, 81.

21 Lihat Mohammad Iqbal, Secrets of the Self: A Philosophical Poem, terj. R. A. Nicholson, Arnold-Heinemann, (New Delhi, 1978), 48.

22 Ibid. 100. 
dengan dengan (1) ketaatan pada hukum yang menuntut penguasaan diri, (2) pengendalian diri dengan faqr yang akan menjaga dari penguasaan atas materi, dan (3) mewakili Tuhan dengan diri yang mampu menyatukan pemikiran dan tindakan serta insting dan penalaran. ${ }^{23}$

Dalam berbagai pemikirannya Iqbal merujuk pada semangat Nabi dan para sahabat, tanpa mengandaikan perwujudan masa lalu ke masa kini. Ia hanya berkepentingan menyaring nilai-nilai dan semangat serta respon kreatif menghadapi kehidupan. Karena itulah cerminan Islam sejati yang diambil dari ajaran-ajaran alQur'an yang non dikotomik, memandang segalanya sebagai satu kesatuan, antara fisik dan jiwa, pikiran dan tindakan, mistisisme dan rasionalisme, Barat dan Timur. ${ }^{24}$ Al-Qur'an juga dilihat Iqbal sangat menentang segala bentuk tirani, termasuk tirani rasionalitas serta tradisi yang stagnan dan anti-perubahan.

Kedua, Sayyid Quthub. Sikap utama Quthub adalah menolak modernitas karena menggambarkan penafian terhadap kedaulatan tuhan di segala bidang kehidupan dan pencampakan agama. ${ }^{25}$ Sebagai propagandis Ikhwanul Muslimin Mesir tahun 1950-an, Quthub memang dipersepsi banyak orang merujuk pada sumber Islam murni semata. Tapi juga penting dicatat bahwa ia tidak menginginkan kembali ke Dunia Islam "tradisional" baik merujuk ke tradisi abad 7 atau lainnya. Ia juga tidak bertujuan utama pada mobilisasi sosial, pertumbuhan ekonomi dan partisipasi politik. Ia tidak bekerja dalam kerangka mendekatkan Islam dengan gagasan keagamaan Barat yang dijejali rasionalitas sains dan sekularisme masyarakat. Yang menjadi persoalan utamanya adalah bagaimana manusia bisa hidup di dunia dengan menjadi dirinya sendiri, bagaimana manusia bisa mengatasi insting dasarnya demi kualitas spirtualnya dalam dunia yang dipenuhi keserakahan, kepentingan pribadi, materialisme dan rasionalitas impersonal. ${ }^{26}$ Karena itu ia juga dinilai melawan kemodernan dengan cara yang modern. ${ }^{27}$

23 Mohammad Iqbal, Reconstruction of Religious Thought in Islam, (Lahore: Ashraf, 1982), 57.

24 Lihat Pengantar Recontruction, hlm. v. Lihat juga Mohammad Iqbal, Thoughts and Reflections of Iqbal, ed. syed Abdul Vahid, (Lahore: Ashraf, 1964), 163.

25 Emanuel Sivan menilai Quthub menolak total modernitas karena membuang Tuhan dan agama. Menurutnya, inilah salah satu model teologi pertengahan dalam baju politk Islam modern. Lihat Emanuel Sivan, Radical Islam: Medieval

Theology and Modern, (New Haven: Politics Yale University Press, 1985), 28.

26 Robert D. Lee, Mencari Islam, 99

27 Ibid. 
Terlihat bahwa Quthub hendak membangkitkan spiritualitas tanpa harus mundur dari dunia dan tanpa monastisisme. Radikalismenya terletak pada upayanya untuk membebaskan manusia dari segala yang dapat menghalangi realisasi potensi yang diciptakan Tuhan. Baginya, manusia berbeda dengan binatang karena intelek dan ruhnya. Maka manusia autentik hakikatnya adalah manusia yang lepas dari watak kebinatangan yang terjerat dalam pemenuhan kebutuhan fisik, khayali, pengejaran kesenangan dan kenikmatan sesaat. Manusia autentik adalah manusia yang menjadikan dirinya sebagai wujud, pasrah pada sumber wujud dan menyerahkan sepenuhnya kepada Tuhan. Dengan demikian mereka akan masuk pada kebebasan sejati sebagai tujuan agama. Ia, seperti juga Iqbal, tidak hanya ingin menghapus ketidakadilan sosial, tapi mendorong manusia mampu mentransformasi diri menuju fitrahnya yang primordial, tulus dan paling adil. ${ }^{28}$

Pandangan dasar ini yang juga digunakan untuk mengkritik Barat karena telah memasung manusia pada kebinatangan, menjebak dalam sekularisme dan dikendalikan oleh kebutuhan ekonomis, sosial dan politik. Semua itu telah mengalienasi manusia dari dirinya sendiri. Menurut Quthub, saat ini kabut yang menyelimuti fitrah manusi lebih tebal, bukan karena kebodohan, tapi karena kesemberonoannya, ${ }^{29}$ yang juga ia sebut sebagai jahiliyah. ${ }^{30}$

Penolakan radikalnya terhadap Barat dengan modernitasnya juga ia alamatkan kepada masyarakat Islam yang dianggapnya tidak Islami. Baginya, di dunia ini hanya ada dua peradaban: Islam dan jahiliyah. ${ }^{31}$ Karena jahiliyah bukan hanya merujuk pada suatu periode, tapi merujuk pada kondisi manusia, keadaan pikiran, kualitas masyrakat dan jalan hidup di mana sistem Islam di banyak tempat dan waktu terabaikan. ${ }^{32}$ Kondisi tersebut adalah kondisi sekuler, ateis, keyakinan pada materialisme-determinisme ekonomi sehingga mereduksi tujuan hidup pada pemenuhan

28 Sayyid Quthub, Hadza al-Din, (Kairo: Dar al-Qalam, 1962), 30.

29 Ibid. 84.

30 Tapi istilah jahiliyyah al-qarn al-isyrin (jahiliyah abad XX) yang populer justru dari merupakan judul buku yang ditulis saudaranya sendiri, Mohammad Quthubu, Jahiliyah al-Qarn al-'Isyrin. Istilah "jahiliyah" sebenarnya merujuk pada tulisan-tulisan Abu al-A'la al-Maududi yang menilai banyak sisi kehidupan modern yang merupakan "kejahatan". Lihat Issa J. Boullata, Dekonstruksi Tradisi, 81.

31 Lihat Sayyid Quthub, Ma'alim al-Thariq, (Kairo: Maktabah Wahbah, 1964), 173.

32 Ibid. 224. 
kebutuhan lahir semata. Hal itu ditolak karena dua alasan: (1) merupakan nilai yang terlepas dari petunjuk Tuhan dalam alQur'an dan syari'at, dan (2) menuju satu tujuan yang menyimpang dari tujuan Islam. Bahkan keyakinan politeistik India, Jepang bagian dunia lainnya juga tergolong jahiliyah. ${ }^{33}$

Maka untuk mencari otentisitas, umat Islam harus kembali ke aturan-aturan Tuhan yang bersifat universal dan menjanjikan kebahagiaan kehidupan dan tidak lagi diperbudak oleh kehidupan duniawi. Hal itu dapat dilakukan dengan meniru garis perjuangan Nabi Muhammad saw, yakni membawa komunitas dari jahiliyah menuju komunitas Islami yang beriman dan hidup dengan aturan Tuhan. Mereka kemudian menjadi ummah yang berjuang untuk memisahkan diri dari masyarakat jahiliyah dan mewujudkan masyarakat Islam sendiri. Mereka itulah yang disebut hizbullah (partai Tuhan). ${ }^{34}$ Walaupun demikian, ia tidak menyebut model politik secara khusus. Baginya, yang penting suatu masyarakat merujuk pada ide tentang kesatuan ras, sifat dan asal usul manusia serta keyakinan bahwa Islam adalah ajaran abadi. Maka dari sana dirumuskan aturan yang didasarkan pada keadilah (' $a d l$ ) pembuatnya, kepatuhan (tha'at) yang diatur serta permusyawaratan (syura) antara yang diatur dan yang mengatur. ${ }^{35}$

Pemikiran Quthub memang terlihat sangat idealistik, bahkan mungkin ahistoris. Karena ia tidak mau memahami kondiri masyarakat lebih jauh. Ia hanya melihat ajaran yang dianggap universal dalam Islam lalu disusul dengan penolakan radikalnya terhadap modernitas dan segala yang dianggap tidak sesuai dengan Islam autentik versinya.

Ketiga, Ali Syari'ati. Seperti Iqbal dan Quthub, Ali Syari'ati juga berbicara tentang autentisitas dalam konteks melepaskan diri dari belenggu tradisi sebagai representasi stagnasi dan cengkeraman modernitas sebagai reprsentasi perubahan yang dibawa Barat. Tapi ia banyak belajar dari kasus khas di negaranya Iran, dari keberadaan kaum Mullah dan para ulama tradisional serta rezim Reza Pahlevi. Bagi Syari'ati, tradisi dan modenitas sama telah mengurung manusia dalam kekaburan identitas diri. Ia sama-

33 Ibid. 125-128.

34 Sayyid Quthub, Hadza al-Din, 84.

35 Sayyid Quthub, Al-'Adalah al-Ijtima'iyyah fi al-Islam, (Kairo: Dar al-Ihya' al'Arabiyah, 1954), 94-99. Bagi Quthub, sistem politik yang menjalankan nilainilai tersebut adalah politik Islam apapun bentuk dan namanya. Sebaliknya, bukan politik Islam jika tidak melaksanakannya sekalipun berlabel Islam. Lihat pada halaman 98 dalam buku yang sama. 
sama melahirkan imitasi dan pengulangan, menyajikan kehidupan yang tidak kreatif dalam menghadapi persoalan kehidupan. Keduanya sama-sama menghilangkan otentisitas Islam, melenyapkan Islam dalam tradisi dan modenitas.

Tradisi yang dikecam Syari'ati adalah tradisi Syi'ah, ${ }^{36}$ sebagai salah satu perwujudan Islam yang kehilangan watak revolusioner. Tradisi ini telah menelorkan "dampak alienatif" yang menjadikan sejarah umat Islam sebagai "kuburan" yang kelam dan sunyi, hanya berisi pengulangan dan imitasi. Hidup, pemikiran dan harapan kemudian mejelma menjadi kebiasaan dan pewarisan. Budaya, peradaban, seni dan iman sekedar menjadi batu-batu mati. ${ }^{37}$ Islam di tangan para tokoh agama menjadi agama yang mandeg, sementara para pemikir tercerahkan justru tidak memahami agama. Akibatnya Islam sejati menjadi hilang. ${ }^{38}$ Secara umum, kata Syari'ati, Islam sejati terhina bukan oleh lawan militer atau politik Islam, tapi oleh para pendukungnya sendiri, kaum tradisional, ulama, mufasir, khalifah dan sebagainya. ${ }^{39}$ Pertempuran yang sebenarnya adalah antara Islam tradisi dengan "Islam sejati", agama sejati dan agama candu.

Sementara gugatan terhadap Barat modern, karena ia telah melahirkan kolonialisme dalam kehidupan secara umum. Ia jelas tidak menggugat modernitas secara umum sebagaimana pada tingkat tertentu dilakukan Quthub, tapi lebih melihat pada kolonialisme yang mencoba menyebarluaskan kebudayaan universal yang tunggal dan asing dalam rangka mebentuk himpunan konsumen yang tunggal dan seragam. ${ }^{40}$

Walaupun demikian, dua arus budaya yang menjadi sasaran kritik Syari'ati dianggap juga menyimpan obat sekaligus. Tradisi dinilai sebagai bagian dari masa silam yang sangat penting untuk membangun masa depan. Arti penting tradisi terlihat pada kreativitas Barat dalam mengolahnya sehingga bisa menciptakan kebudayaan baru dari sumber-sumber budayanya sendiri. Kesalahan orang Iran adalah kegagalan meniru Barat dalam mengolah tradisi. ${ }^{41}$ Di sini terlihat bahwa kritik Syari'ati atas Barat memang tidak sesengit kritiknya terhadap tradisi.

36 Dalam hal ini Syi'ah Hitam, yang konservatif, anti perubahan dan otoriter.

37 Dikutip Robert D. Lee, Mencari Islam, 139, dari Ali Syari'ati, Histoire et destinée, terj. F. Haméd dan N. Yavari-d'-Hellencourt, (Paris: Sinbad, 1982), 29.

38 Ali Syari'ati, What is to be Done, (Huston: Institute for Research and Islamic Studies, Houston, 1996), 21.

39 Ali Syari'ati, What is, 38.

40 Robert D. Lee, Mencari Islam, 17.

41 Ali Syari'ati, Art Awaiting the Savour, terj. Homa Fardjadi, (Huston: Free Islamic Literatures, 1980), 10. 
Yang unik dari Syari'ati adalah penilaiannya bahwa Islam sejati hanyalah salah satu jalan menuju kemajuan. Karena Islam tidak dapat digunakan sebagai titik awal pencarian dalam satu budaya non-Islam. Yang lebih prinsip adalah "pencerahan", yakni gerakan yang mampu mencetak pribadi yang sadar akan kondisi kemanusiaannya di dalam waktu dan latar belakang sosial dan kesejarahan, dan yang kesadarannya mampu memberinya tanggung jawab sosial. ${ }^{42}$

Sementara, Islam yang bisa membawa pada kemajuan adalah Islam sejati yang ia sebut "Islam revolusioner", sebuah ideologi revolusioner yang bisa membangkitkan cita-cita yang dapat mentransformasi sistem, lingkungan dan relasi sosial. ${ }^{43}$ Untuk itu diperlukan empat metode: (1) kajian sejarah Islam, terutama masa awal, (2) kajian tentang dunia kontemporer, (3) pendalaman atas teks-teks Islam, (4) penyelaman atas elemen paling mistis agama. ${ }^{44}$

Melihat sejarah Islam harus dilakukan dengan cerdas, dengan melihat dalam konteks sosiologis, bagaimana Nabi Muhammad membangun masyarakat baru dengan kemampuan mengolah tradisi yang ada melalui pengubahan isi, jiwa dan arah tradisi praIslam serta aplikasi praktisnya dengan cara revolusioner. Misalnya pada tradisi ziarah dan pusat Ziarah, Ka'bah. ${ }^{45}$ cara-cara tersebut ia sebut "metode Muhammad", yang manusiawi dan historis, bukan metode Tuhan. ${ }^{46}$ Sedang kajian atas dunia kontemporer menjadi penting untuk memahami persoalan yang terjadi saat ini pada masyarakat Islam. Dalam konteks Syi'ah Iran, inilah yang ia lihat dalam kasus perubahan "Syi'ah Merah" yang dinamis dan melawan tirani ke Syi'ah Hitam" yang birokratis, statis dan otoriter pada Dinasti Syafawi hingga masa hidupnya. Hal itu harus didukung dengan penguasaan atas warisan khazanah Islam yang tidak tekstual berikut dimensi paling mistis agama yang mampu menyentuh nurani terdalam umat Islam.

Bekal tersebut di atas digunakan oleh Syari'ati untuk mendongkel dogma yang dijadikan basis Islam secara tekstual dan menggantinya dengan pemahaman sesuai dengan kehidupan aktual. Pemahaman tajam atas kondisi aktual tersebut berkat

42 Ali Syari'ati, What is, 4. Lihat juga pada halaman 69.

43 Robert D. Lee, Mencari Islam, 140.

44 Untuk bacaan lebih lanjut tentang "Syi'ah Merah" dan "Syi'ah Hitam," lihat Ali Syari'ati, Red Syi'ism, terj. Habib Shirazi, (Huston: Free Islamic Literatures, 1980).

45 Lihat lebih lanjut Ali Syari'ati, Fatima is Fatima, terj. Laleh Bakhtiar, (Tehran: Syari'ati Foundation, 1980), 65.

46 Robert D. Lee, Mencari Islam, 141. 
kemampuannya menggunakan ilmu-ilmu sosial yang diambil dari Barat, khususnya saat kuliah di Paris.

Keempat, Mohammed Arkoun. Pencarian otentisitas cenderung kembali pada ortodoksi yang didukung oleh nalar Islam. Hal itu terlihat dari istilah ashalah yang berasal dari kata ashl dan juga membentuk kata ushul. Akhirnya muncul istilah ushul fiqh atau ushul al-din yang telah menjadi disiplin mapan. Justru merujuk pada ortodoksi sebagai jalan pencarian untuk menemukan kembali jati diri membuat umat Islam teralienasi. ${ }^{47}$

Bagi Arkoun, pencarian otentisitas tidak mesti dicari dari ortodoksi yang dibangun oleh nalar Islam yang telah mapan. Yang penting adalah "cara mengada atas kesadaran sendiri dalam kehidupan saat ini." Karena persoalannya adalah menatap realitas kehidupan yang telah berubah cepat di bawah modernitas Barat yang mengglobal. "Apa yang mesti dilakukan seorang muslim" adalah pertanyaan dasarnya. Maka otentisitas merupakan sebuah kreativitas dan kehendak yang menggelora, bukan sekedar pengulangan tradisi dan rutinitas.

Tentu saja usaha pencarian otentisitas juga harus merujuk pada sejarah sebagai upaya pembacaan atas masa lalu untuk kepentingan masa depan. Hal itu tentu akan berujung pada wahyu. Tapi jika kaum muslimin hendak mencari tahu tentang kebenaran dirinya, maka mereka tidak hanya harus mengkaji ulang kebenaran wahyu, tapi juga mengkaji ulang semua cara khas yang membuat kebenaran itu dipahami, dirasakan, dielaborasi, dijustifikasi, diberi wajah ortodoksi dan dihayati dalam konteks ruang dan waktu tertentu. ${ }^{48}$

Untuk kepentingan ini, diperlukan beragam ilmu modern seperti sosiologi, antropologi, linguistik, semiotik dan hermeneutik. Karena kebenaran yang diwarisi mengalami sakraslisasi dan transendentalisasi, maka titik tolak kajian Arkoun adalah dekonstruksi konsepsi sejarah dan kebudayaan Arab-Islam, yang semata merupakan produk aktivitas manusia dalam ruang dan waktu tertentu, yang disebut Arkoun "historisitas" (tarikhiyyah). Karena itu ia tidak bisa diuniversalisasi, apalagi disakralkan dan ditransendensikan. ${ }^{49}$

47 Ibid. 167.

48 Mohammed Arkoun, "Society, State and Religion in Algeria," dalam The Politics of Islamic Revivalism, Shireen T. Hunter (ed.), (Bloomington: Indiana University Press, 1988), 183.

49 Mohammed Arkoun, Tarikhiyyat al-Fikr al-'Arabi al-Islami, (Beirut: Markaz alInma' al-Qaumi, 1986), 24-29. Secara lebih gamblang, penggunaan ilmu-ilmu "modern" menjadi sangat penting untuk memetakan kinerja keilmuan klasik 
Dengan dekonstruksi sejarah yang dilanjutkan dengan analisis epistemologis, Arkoun hendak menunjukkan bahwa pemaknaan terhadap al-Qur'an telah ditransformasikan ke dalam kategori-kategori ideologis yang kemudian dibakukan sehingga menjadi "tertutup" dengan mengabaikan dimensi historisitas dan manusiawinya. Dengan demikian, banyak hal yang "tak dipikiran" (unthought-of/al-la mufakkar fih) dan dalam perkembangannya juga melahirkan hal-hal yang tak terpikiran (unthingkable/mustahil al-tafkir fih)..$^{50}$ Padahal diketahui bahwa kebenaran yang terdapat dalam turats pada mulanya merupakan respon kreatif yang bebas dan dibangun berdasarkan sisten kognitif secara gradual berdasar kondisi sosial ekonomi dan politik hingga akhirnya menetapkan hal-hal yang "terpikiran". 51

Dengan kritik tersebut Arkoun telah menunjukkan bagaimana sikap modern terhadap turats, yakni sikap kritis, terbuka dan menyadari historisitasnya sehingga tidak terjadi sakralisasi dan transendetalisasi. Sikap atas turats sebagaimana dicontohkan menjadi penting untuk menatap modernitas. Menurut Arkoun, kaum muslim masih gagap menghadapi modernitas, terutama karena beban psikologis sehingga sering melahirkan apologi dengan menyebut kemajuan Barat berkat Islam masa lalu. ${ }^{52}$ Maka melepaskan beban psikologis dengan melihat modernitas sebagaimana adanya dengan kelebihan dan kekurangannya menjadi salah satu agenda.

Untuk upaya ini Arkoun menegaskan bahwa masing-masing peradaban sama-sama memiliki dua kutub yang saling berkaitan (1) unsur lama: yang kuno, tradisional dan klasik; (2) kutub masa depan, inovasi orientasi masa depan, cakrawalan yang luas. Kemajuan terdiri dari konvergensi kreatif antara keduanya, antara

sehingga bisa ditemukan unsur-unusur historis dan manusiawi yang mempengaruhi munculnya ilmu-ilmu klasik di formative age ('ashr al-tadwin) tersebut. Lihat M. Amin Abdullah, "Arkoun dan Kritik Nalar Islam," dalam Johan Hendrik Meuleman (ed.), Tradisi, Kemodernan dan Metamodernisme, Memperbincangkan Pemikiran Mohammed Arkoun, (Yogyakarta: LKiS, 1996), 13.

50 Mohammed Arkoun, Tarikhiyyat al-Fikr, 188.

51 Kajian lebih luas dapat dilihat dalam Mohammed Arkoun, Al-Fikr al-Arabi, terj. Adil al-Awwa', (Beirut: Mansyurat Uwaidah, 1983), terutama Bab II dan III.

52 Mohammed Arkoun, Al-Islam, Ashalah wa Mumarasah, terj. Khalil Ahmad, (Beirut: Mansyurat Uwaidah, 1986), 40. Bahkan banyak pemikiran muslim yang menyebut beberapa unsur budaya Barat seperti demokrasi dan kemajuan ilmu pengetahuan sudah dilakukan oleh umat Islam dan ajaran dasarnya terdapat dalam al-Qur'an. 
turats dan hadatsah dalam wacana Arab-Islam. ${ }^{53}$ kesadaran untuk menggabungkan itu harus disertai kecakapan memilih unsur modernitas yang cocok. Dalam hal ini Arkoun membagi unsur modernitas menjadi: (1) unsur material, (2) intelektual atau budaya. Yang pertama merupakan wujud luar yang kongkrit sedang yang kedua mencakup berbgaimetode, alat analisis dan sikap intelektual untuk memahami realitas. ${ }^{54}$ Mengejar aspek material modernitas tidak akan memberikan kemajuan, demikian pula mengambil aspek intelektual jika tidak disertai otentisitas yang digali dari turats hanya akan melahirkan imitasi yang tidak kreatif serta pengulangan.

Maka sikap otentik menghadapi modernitas bagi umat Islam adalah menggali turats dengan perangkat modern sebagai bekal bagi perubahan yang harus dilakukan dalam kehidupan ke depan disertai sikap terbuka dan kritis atas unsur-unsur modernitas. Dalam hal ini tampak bahwa upaya Arkoun lebih bersifat intelektual dari pada tiga tokoh sebelumnya dengan perangkat akademik yang lebih lengkap karena melibatkan kinerja epistemologis lebih luas.

\section{Kesimpulan}

Pencarian otentisitas hakikatnya adalah pencarian "yang sebenarnya" dari pada "yang tampak", yang fundamental dari pada yang superfisial. Pencarian ini menjadi penting karena umat Islam mengalami "alienasi" dalam kehidupan kontemporer. Bentuk alienasi tersebut adalah kegagapan menghadapi perubahan akibat modernitas, ketidakmampuan memecahkan berbagai persoalan baru yang muncul serta lahirnya sikap-sikap yang tidak elegan.

Di satu sisi, umat Islam ingin mempertahankan budayanya sendiri, tapi di sisi lain dituntut melakukan perubahan. Mempertahankan tradisi yang dibentuk dari nalar abad tengah tentu saja tidak akan melepas dari alienasi dari kehidupan. Tapi memodernisasi diri dengan berkiblat ke Barat sementara ia memiliki latar belakang budaya yang berbeda juga tidak akan melepas dari kungkungan alienasi. Dua sikap yang banyak diambil oleh masyarakat Islam ini sama-sama tidak bisa memposisikan umat Islam dalam kehidupan kontemporer dengan turut ambil bagian dalam kehidupan.

Iqbal yang filosofis, Sayyid Quthub yang radikal, Ali Syari'ati yang revolusioner dan Arkoun yang kritis telah turut memberikan

\footnotetext{
53 Ibid, 43.

54 Ibid.
} 
sumbangannya. Secara umum keempat tokoh tersebut sama-sama menggugat tradisi yang stagnan dan mengkritisi modernitas yang mengemban nilai-nilai negatif. Keempat tokoh itu sama-sama menyerukan perubahan untuk membangunkan umat Islam dari ketertinggalan akibat "alienasi" dan "krisis identitas." Hanya saja masing-masing berbeda dalam memposisikan Islam. Quthub yang tampak "idealistik totaliter", menjadikan Islam sebagai jalan kebenaran satu-satunya, sementara Syari'ati hanya menganggap sebagai salah satu jalan dengan memperbarui makna-makna nilai dasar. Itu juga yang terlihat pada Iqbal dengan penekanan pada pemahaman diri yang filosofis. Bagi Arkoun, tradisi penting tapi harus didekosntruksi untuk kemudian direkonstruksi. Perbedaan itu tak lepas dari latar belakang pendidikan serta pengalaman hidup berikut interaksinya dengan Barat.

Masing-masing sumbangan tersebut tentu sangat penting terlepas dari setuju atau tidaknya. Karena itu, salah satu uji kehandalan sumbangan para pemikir itu -salah satunya-terletak pada nilai praktisnya dalam kehidupan saat ini. Seperti dikatakan Syari'ati, tidak ada jalan universal menuju kebangkitan umat. Demikian juga, tak ada cara universal bagi pencarian otentisitas. Masing-masing pemikiran tetap memiliki lokalitas dan manusiawinya sehingga tetap diperlukan sikap kritis dari kreatif untuk menyikapinya. Keempat tokoh tersebut sudah mengajarkan bagaimana bersikap kreatif melihat persoalan dasar, meracik tradisi dan modernitas dalam dunia yang berubah cepat.

\section{Daftar Pustaka}

Abdullah, M. Amin. "Arkoun dan Kritik Nalar Islam," dalam Johan Hendrik Meuleman (ed.), Tradisi, Kemodernan dan Metamodernisme, Memperbincangkan Pemikiran Mohammed Arkoun, (Yogyakarta: LKiS, Yogyakarta, 1996).

Arkoun, Mohammed. Al-Fikr al-Arabi, terj. Adil al-Awwa', (Beirut: Mansyurat Uwaidah, 1983).

Arkoun, Mohammed. Al-Islam, Ashalah wa Mumarasah, terj. Khalil Ahmad, (Beirut: Mansyurat Uwaidah, 1986).

Arkoun, Mohammed. Tarikhiyyat al-Fikr al-'Arabi al-Islami, (BeirutP Markaz al-Inma' al-Qaumi, 1986). 
Arkoun, Mohammed. "Society, State and Religion in Algeria," dalam The Politics of Islamic Revivalism, Shireen T. Hunter (ed.), (Bloomington: Indiana University Press, 1988).

Assyaukani, Luthfi. "Tipologi dan Wacana Pemikiran Arab Kontemporer," Jurnal Paramadina, Vol. I, No. 1, JuliDesember,1998.

Boullata, Issa J. Dekonstruksi Tradisi, Gelegar Pemikiran Arab Islam, terj. Imam Khoiri, (Yogyakarta: LKiS, 2001).

Hanafi, Hasan. Muqaddimah fi 'Ilm al-Istighrab, (Kairo: Maktabh Wahbah, 1991).

Iqbal, Mohammad. Poems from Iqbal, terj. V.G. Kiernan, Murray, (London, 1955).

Iqbal, Mohammad. Thoughts and Reflections of Iqbal, ed. Syed Abdul Vahid, Lahore: Ashraf, 1964).

Iqbal, Mohammad. Secrets of the Self: A Philosophical Poem, terj. R. A. Nicholson, Arnold-Heinemann, (New Delhi, 1978).

Iqbal, Mohammad. Reconstruction of Religious Thought in Islam, Lahore: Ashraf, 1982).

Jabiri, Mohammad Abid al-. Nahnu wa al-Turats, (Beirut: Al-Markaz al-Tsaqafi al-'Arabi, 1993).

Lee, Robert D. Mencari Islam Autentik, Dari Nalar Puitis Iqbal sampai Nalar Puitis Arkoun, terj. Ahmad Baiquni, (Bandung: Mizan, 2000).

Nasution, Harun. Pembaharuan Dalam Pemikiran Islam, (Jakarta: Bulan Bintang, 1980).

Quthub, Sayyid. Al-'Adalah al-Ijtima'iyyah fi al-Islam, (Kairo: Dar alIhya' al-'Arabiyah, 1954).

Quthub, Sayyid. Ma'alim al-Thariq, (Kairo: Maktabah Wahbah, Kairo, 1964).

Rahman, Fazlur, "Iqbal and Mysticism," dalam Iqbal as a Thinker, (Lahora: Ashraf, 1944).

Sahidah, Ahmad. "Menemukan Islam Otentik: Menggugat Tradisi dan Modernitas," Jurnal Kontekstualita, Vol. 25, No. 2, 2010.

Susanto, Edi. "Islam Pribumi versus Islam Otentik (Dialektika Islam Universal dengan Partikularitas Budaya Lokal," Jurnal Karsa, Vol. VIII, No 1, April 2008.

Sivan, Emanuel. Radical Islam: Medieval Theology and Modern (New Haven: Politics Yale University Press, 1985.

Syari'ati, Ali. Art Awaiting the Savour, terj. Homa Fardjadi, (Huston: Free Islamic Literatures, 1980).

Syari'ati, Ali. Fatima is Fatima, terj. Laleh Bakhtiar, (Tehran: Syari'ati Foundation, 1980). 
Syari'ati, Ali. Red Syi'ism, terj. Habib Shirazi, (Huston: Free Islamic Literatures, 1980).

Syari'ati, Ali. What is to be Done, (Huston: Institute for research and Islamic Studies, 1996).

Wardi, Moh. "Hermeneutika Khaled Abou El Fadl; Sebuah Kontribusi Pemikiran Dalam Studi Islam" Jurnal Al-Ulum; Jurnal Pemikiran dan Penelitian Keislaman UIM Pamekasan, Vol. 1 No. 1 Juni 2014.

Vahid, Syed Abdul. Iqbal, His Art and Thought, (Lahore: Ashraf, Lahore, 1944). 